кандидат педагогічних наук, доцент кафедри педагогіки, професійної освіти та управління освітніми закладами Житомирського державного університету імені Івана Франка

ORCID: 0000-0003-0780-0580 e-mail: inesanovicka@gmail.com

Ігор Вербовський, старший викладач кафедри професійної освіти та управління освітніми закладами Житомирського державного університету імені Івана Франка ORCID: 0000-0001-7202-3429 e-mail: super iagrik2011@ukr.net

Людмила Лисюк, викладач кафедри комп’ютерних наук та інформаційних технологій Житомирського державного університету імені Івана Франка

ORCID: 0000-0002-3713-9378 e-mail: lisiuk_lp@ukr.net

\title{
АНАЛІЗ НАПРЯМІВ МОДЕРНІЗАЦІЇ СУЧАСНИХ ПЕДАГОГІЧНИХ СИСТЕМ В УМОВАХ ГЛОБАЛІЗАЦІЙНИХ ЗМІН
}

У статті розглядаються сучасні тендениії модернізації освіти, які зумовлені швидкими змінами традиційних механізмів соціалізації людини та становленням високорозвиненого суспільства загалом. Визначено, щзо в умовах глобалізаційних змін до основних освітніх

реформ належить: безперервність освіти, ї̈ комп'ютеризація, перехід від школи відтворення до школи мислення, від контрольних методів організації освітнього процесу до інтерактивних форм, автономія та незалежність закладів освіти, доступність та право на освіту для всіх громадян, розширення ринку освітніх послуг, зміна системи управління, пошук компромісів між централізацією та повною автономією.

Ключові слова: модернізачія, педагогічні системи, інновачійні педагогічні системи, становлення сучасної освіти, принщипи сучасної освіти, освітні технології.

Inesa Nowicka, Igor Werbovski, Ludmiła Lisiuk. Analiza kierunków modernizacji nowoczesnych systemów pedagogicznych w warunkach zmian globalizacji

Artykut dotyczy aktualnych trendów modernizacji oświaty, które wynikaja z gwaltownych zmian $w$ tradycyjnych mechanizmach socjalizacji człowieka oraz kształtowania się całości społeczeństwa wysoko rozwiniętego. Ustalono, że w kontekście przemian globalizacyjnych do głównych reform edukacyjnych należy zaliczyć: ciagłość edukacji, jej komputeryzację, przejście ze szkoły reprodukcji do szkoły myślenia, od kontrolnych metod organizacji procesu edukacyjnego do interaktywnych form, autonomię i niezależność placówek edukacyjnych dla wszystkich obywateli; rozszerzenie rynku usług edukacyjnych, zmiana systemu zarzadzania, poszukiwanie kompromisów między centralizacja a petna autonomia.

Stowa kluczowe: modernizacja, systemy pedagogiczne, innowacyjne systemy pedagogiczne, kształtowanie nowoczesnej edukacji, zasady nowoczesnej edukacji, technologie edukacyjne.

Inesa Novitska, Igor Verbovsky, Lyudmila Lisyuk. Analysis of directions of modernization of modern pedagogical systems in the conditions of globalization changes

The article deals with the paradigm tendencies of education modernization. The authors determine education as a way for a person to enter into the integral existence of culture and society, as a complex social organism, the main functions of which are the reproduction of experience accumulated in culture, its transmission from generation to generation. At a time when society is undergoing rapid change, when the traditional mechanisms of socialization and acculturation of a 
Інеса Новіџька, Ігор Вербовський, Людмила Лисюк. Аналіз напрямів модернізації сучасних педагогічних систем в умовах глобалізаційних змін

person face significant challenges, reforming the education system is not just an urgent task among other aspects of the life of the individual human community, but a global problem of humanity as well.

Among the current trends in educational reforms during the processes of globalization pointed out the next ones: continuity of education, its computerization, the transition from school of reproduction to school of thinking, from control methods of organizing the educational process to interactive forms, access to education, autonomy and independence of educational institutions, the right to education for all citizens, expanding the market of educational services, changing the management system, finding compromises between centralization and full autonomy. Thus, the concept of globalization can be generalized as a process of economic, political and social systems, which involves the intensification of competition between countries in various fields of science and

social life and promotes the development of international cooperation and integration.

The education system must be constantly changing to respond to modern globalization processes. Among the negative consequences there are: loss of national identity and educational traditions. Thus, the reform of education in today's globalized society is based on the principles of humanization, democratization, accessibility and autonomy. Currently, the main tasks of education are the competitiveness of graduates in the labor market, including abroad, increasing the mobility of participants in the educational process and more

Keywords: modernization, pedagogical systems, innovative pedagogical systems, formation of modern education, principles of modern education, educational technologies.

Постановка проблеми в загальному вигляді та їі зв'язок з важливими науковими й практичними завданнями. Становлення сучасної системи освіти вимагає постійного пошуку та модернізації сучасних педагогічних систем, які зможуть відповідати потребам не лише українського суспільства, а й міжнародним стандартам. Однак, надшвидкі темпи розвитку навколишнього світу зумовлюють повністю змісти орієнтири збереження людського ресурсу, котрий відіграє ключову роль в існуванні самого світу, а саме: модернізувати українське суспільство під потреби самої людини, що, у свою чергу, зумовило зростання ролі освіти, іï якості та доступності. Нинішні випускники закладів - це вже не просто кваліфіковані спеціалісти, це висококваліфіковані, конкурентоспроможні фахівці, які конструктивно мислять, знаходять компромісні рішення в будь-якій ситуації й знають моделі самовдосконалення та саморозвитку тощо. Українська система освіти й наявний потенціал нації до сьогодні дозволяє Україні утримуватися в середині розвитку та глобальної конкурентоспроможності серед ряду країн світу, однак є нагальна потреба становлення інноваційного члена суспільства, котрий розуміє всі глобалізаційні зміни та відповідні виклики й потреби.

Аналіз основних досліджень та публікацій із зазначеної проблеми. На важливість модернізації сучасних педагогічних систем в умовах глобалізаційних змін указують ряд національних доповідей на основі аналізу здобутків й прорахунків системи дій та заходів 3 модернізації освіти, зокрема, Біла книга національної освіти (2010р.), Національна доповідь про стан і перспективи розвитку освіти в Україні (2011 р., 2016 р.), Національна доктрина розвитку освіти, закони України «Про освіту» (1991 р., 2017 р.), «Про вищу освіту» (2002 р., 2014 р.), «Про наукову і науково-технічну діяльність» (1991 р., 2015 р.), низка наукових досліджень (кандидатські та докторські дисертації, науково-дослідні роботи, грантові досліження тощо).

Модернізація сучасних педагогічних систем вимагає вдосконалення технологій педагогічного проектування та його оптимізації. Дані питання були предметом дослідження в наукових працях В. Докучаєвої, В. Краєвського, І. Лернера та ін. Загалом питання проектування освітнього процесу аналізували О. Коберник, А. Кочнєв, О. Мещеряков, Г. Муравйова, В. Попов та ін. модернізація освітніх та навчальних планів, методичних систем стали предметом дослідження Г. Афанасьєва, О. Спіщева, Д. Матрос, В. Радіонова, 
Т. Смиковської, Е. Сундукова та ін. Відомі не лише в Україні, а й за іï межами науковці В. Беспалько, 3. Мазур, В. Монахов, Ю. Чернова та інші досліджували проектування педагогічних технологій. Сьогоднішня система освіти вимагає удосконалення проблеми впровадження особистісно розвивальних педагогічних засобів, регіональних систем освіти та проектування виховних систем.

Модернізація педагогічних систем у вищій школі представлена в роботах I. Гладка, Н. Докучаєвої, Ю. Євсєєва, К. Задоріна, С. Ільїна, Л. Іванової, О. Коберник, В. Костіна, Т. Семенюк. Щодо процесів формування проектної культури суб'єктів освітнього процесу, то ці питання вивчені А. Кравцовим, Г. Муравйовою та ін. Формування фахової компетентності майбутніх педагогів та підготовку до освітньої діяльності досліджували О. Антонова, Н. Білик, Н. Гузій, В. Демидова, О. Дубасенюк, І. Зязюн, Н. Кузьміна, О. Савченко та ін.

Процеси модернізації педагогічних систем вимагають удосконалення й інноваційної педагогічної діяльності (В. Алфімов, І. Гавриш, Т. Демиденко, А. Каташов, Л. Твердохліб та ін.), оскільки ті чи інші зміни дозоляють створювати щось нове. Власне це зумовлює не лише створення теорії інноваційних процесів в освіті, а й опанування теоретико-прикладного світового досвіду щодо розробки інноваційних процесів у системі освіти, узагальнення методології педагогічної інноватики $[1 ; 2 ; 6 ; 7 ; 10]$.

Теорії виникнення нового та дослідження відповідних творчих процесів були і $\epsilon$ ключовими проблемами таких наук, як філософія, педагогіка, психологія, акмеологія та інших теоретико-методологічних дисциплін, про що засвідчують наукові праці М. Вертгеймера, Л. Виготського, П. Копніна, В. Кременя, А. Леонтьєва, В. Моляко, Б. Новікова, Я. Пономарьова, С. Рубінштейна. П. Сауха та ін.

Як свідчить аналіз наукового доробку вчених та аналітичні дані, освітня політика в Україні впродовж останніх років «здійснювалася в умовах розширення спектру та збільшення сили трансформаційних впливів європейської інтеграції та світової глобалізації» $[1 ; 2 ; 7]$. Проте в національній освіті $\epsilon$ ще ряд невідповідностей щодо впровадження результатів передової європейської й світової освітянської діяльності.

Тому метою цієї статті $є$ представлення аналізу напрямів модернізації сучасних педагогічних систем в умовах глобалізаційних змін, зокрема узагальнення матеріалу про педагогічні системи, принципи розвитку системи освіти, моделі сучасних педагогічних систем, які допоможуть модернізувати сучасну освіту.

Виклад основного матеріалу 3 обгрунтуванням отриманих наукових результатів. Доречно вказати на те, що напрями модернізації сучасних педагогічних систем в умовах глобалізаційних змін визначаються насамперед станом розвитку суспільства, рівнем розвитку економіки, експортом послуг та градацією системи підготовки спеціалістів відповідних галузей. Власне всі ці процеси збалансовують і модернізують сучасні педагогічні системи, переорієнтовують принципи розвитку системи освіти, удосконалюють моделі сучасних педагогічних систем. Як засвідчує наукова розвідка, нинішній стан розвитку науки й техніки робить акцент на впровадженні та вдосконалені моделей проектування.

Теорія проектування починає активно впроваджуватися й розвиватися ще в 20-х $\mathrm{p}$. минулого століття. Проектування набуває особливого значення, його розглядають системно, як планування, програмування, прийняття рішень, розробки, винаходи, наукові дослідження тощо. Це вже не лише суто конструкторсько-інженерна діяльність, це творчий процес 3 відповідним потенціалом, який випливає й поширюється в соціальних сферах розвитку суспільства, а саме: у культурі, освіті, праці, побуті тощо. Відповідно встановлюються нові вимоги до формування фахівця з творчим потенціалом, який отримує не лише знання, а чітко володіє ними на практиці в різних галузях, прагне не лише створити новий об'єкт, але й змінити ситуацію, створити якісно новий продукт.

Аналіз наукового доробку дозволяє нам стверджувати, що педагогічна система $\epsilon$ циклічним процесом, у ході діяльності якої будемо отримувати новий результат, котрий буде 
у вигляді створеної інноваційної педагогічної системи. Варто пам'ятати, що в такій циклічній взаємодії інноваційна педагогічна система є необхідною умовою подальших змін для досягнення більш значущих цілей. У кожному окремому випадку створення нового інноваційний процес може бути й чинником, і умовою, і технологією [1;7]. Такі зміни в педагогічних системах не повинні бути процесом спрощення чи усунення тих чи тих чинників, а це $є$ процес удосконалення, набуття нового стану тієї чи іншої педагогічної системи. А тому сьогоднішні зміни в системі освіти набувають особливого значення в процесах забезпечення безперервності освіти, iii комп’ютеризації, технологізації, інформатизації, перехід від школи відтворення до школи мислення, від контрольних методів організації освітнього процесу до інтерактивних форм, автономії закладів освіти, права на освіту для всіх громадян, розширення ринку освітніх послуг, зміни системи управління, пошуку компромісів між централізацією та повною автономією. Усе це в комплексі дозволить нашій системі освіти посісти цільне місце на міжнародному ринку послуг, стати полісуб'єктною, формувати конкурентоспроможного випускника, якого потребує не лише Україна, а і європейська спільнота.

У такому спрямуванні державна освітня політика зумовлює зміну ставлення самого суспільства до освіти, їі науково-технічного розвитку та супроводу, упровадження принципів людиноцентризму, створення систем забезпечення якості освітніх послуг, здійснення національного й міжнародного моніторингу, внутрішнього аудиту та аналізу стану й перспектив розвитку освіти, підвищення фінансової стабільності закладів освіти, зростання інтелектуальних ресурсів [7].

Водночас необхідно завжди пам'ятати про концепцію діалектичного заперечення. А тому розвиток педагогічної системи передбачає прогрес і регрес, у ході яких підвищується або знижується сталість систем, їхніх елементів по відношенню до певного середовища [1]. До того ж, створення нового є результатом розвитку, саморозвитку попереднього, а за наявних необхідних умов відбувається прогресивний стрибок і створюється знову щось нове, більш високої якості. Таке перетворення найбільш точно відтворює поняття наступності, яке зі свого боку означає «не лише збереження змісту заперечуваного, але передачу саме позитивного змісту попереднього якісного стану об'єкта наступному, новому» [1].

Загальна соціальна ситуація в Україні вимагає переорієнтації й моделей підготовки майбутніх фахівців, які зможуть зберегти й примножити самобутню національність української національної школи, а відповідно зберегти національну цілісність держави.

3 цією метою вважаємо актуальними ідеї класифікації моделей педагогічного процесу професорки Л. Пуховської, котра розглядає педагогічні системи в соціально-індивідуальній та гуманістичній площинах із врахуванням наявності ряду показників, зокрема: спрямованість педагогічного процесу, його мета й результат; характер взаємодії головних учасників педагогічного процесу; принципи відбору й організації змісту освіти, процесу навчання; педагогічний інструментарій, що використовується; спосіб погодження цілеспрямованої і стихійної соціалізації індивіда; характер взаємодії освітніх інститутів, їх суспільна орієнтація [1; 9, с. 44]. Авторка пропонує модель педагогічного процесу, яка допоможе правильно визначити систему зміни векторів освітньої революції, а саме: педагогічна парадигма, яка вимагає осмислення і визначення педагогічного цілепокладання; опрацювання та врахування соціального замовлення як загальної мети; реалізація виховних парадигм через моделі педагогічної діяльності в межах освітніх інституцій [9, с. 44-46]. Представлена авторкою модель $є$ певним узагальненням спільних ознак моделей педагогічних систем та співвіднесення їх з провідними парадигмами професійної підготовки вчителів за кордоном, зокрема у Польщі, Словенії, Англії, Італії тощо. Зарубіжні парадигми професійної підготовки за кордоном орієнтуються на свободу та автономність самої особистості, іï розвиток, самовдосконалення, самовираження. Так, набуває актуальності особистісно орієнтована модель підготовки педагога, упровадження концепцій «персоналізованої» педагогічної освіти, «школи самореалізації особистості», доступної 
школи для дітей з особливими освітніми потребами, які $є$ актуальними в міжнародному освітньому просторі. Важливим аспектом $є$ впровадження дослідницько-орієнтованої системи освіти, яка надає освіті інноваційності, обумовлює позитивні зміни в існуючій культурі, соціальному середовищі.

Особливе місце сьогодні в процесі модернізації педагогічних систем посідає практична професійна підготовка спеціалістів, запровадження системи дуальної освіти, підвищення сутності педагогічної та наукової практики фахівців у процесі підготовки, засвоєння інноваційного знання в теорії та застосування його в модельованій практиці. Моделювання має характер групового опрацювання та оцінювання ситуацій, дозволяє фахівцю осмислювати себе й своє місце в конкретній ситуації, включає елементи соціальнопсихологічного тренінгу. Упровадження такої системи інноваційної підготовки дозволяє моделювати різні соціальні системи професійної взаємодії, власне так можна побудувати сучасну модель інноваційного закладу освіти й розуміти його як соціальну інституцію. Тобто інноваційний заклад освіти $\epsilon$ педагогічною моделлю й водночас його можна охарактеризувати як соціальну, штучно створену концептуальну, динамічну, регульовану, інформаційну систему, систему яка самоорганізується, саморозвивається, здатна до адаптації в мінливому середовищі, може змінювати свої завдання за постійних умов та засобів їх виконання [1].

У такому разі слід враховувати той момент, що люди зі своєю індивідуальністю утворюють системи, вони є елементами соціальних груп, визначають колективну поведінку, відзначаються цілеспрямованістю та індивідуальністю в системі, співіснують заради досягнення спільної мети, прагнуть до певного результату, обмінюються інформацією, досвідом. Тобто, можна стверджувати, що індивіди роблять систему відкритою й відповідно надають ій життєвого смислу, водночас трапляються певні перешкоди, відхилення, що можуть призводити до нестійкості системи або іiі стійкості та саморозвитку. Ці процеси завжди відбуваються у будь-якій системі, і вони є необхідною умовою для подальшого створення нової системи, іiі розвитку та переходу на більш вищий етап існування, іiі самоорганізації. Важливим є врахування шляхів взаємодії елементів, частин або підсистем 3 метою виходу на успішний рівень самоорганізації й збереження необхідних ресурсів. Якщо проектувати це на педагогічну систему, то можна представити ряд характеристик сучасної інноваційної школи, що утворюють iï як цілісну систему, а саме: сталість; динамічність; самоорганізованість; детермінованість зовнішніми чинниками; здатність до саморозвитку 3 урахуванням зовнішніх і внутрішніх резервів; інтенсивність, модальність, ступінь усвідомлюваності, ступінь стійкості, нестійкість, нестабільність як джерело саморуху; емоційність, узагальненість, домінантність, когерентність, активність, мобільність, здатність до кількісного та якісного збагачення, саморозвитку на засадах науково обгрунтованого інноваційного процесу; зорієнтованість системи на співрозвиток іiі компонентів, частин i підсистем 3 урахуванням їх власних особливостей, тенденцій розвитку; здатність змінювати шляхи свого розвитку за умови перебудови структурних елементів системи та їі соціального оточення та ін. [1;6].

Як свідчить практика, будь-які нововведення та зміни мають позитивні наслідки для існування педагогічних систем, що представлено вище. Проте існує й інша негативна сторона, яка виділяє чинники проблеми самоорганізації системи, а саме: соціальні відносини 3 приводу нововведень, опір і несприйняття нового. Інноваційний розвиток педагогічної системи передбачає співпрацю авторів ідей, проектів, фахівців, які планують, фінансують інноваційний процес, забезпечують упровадження нововведення та користувачів, які працюють з ними.

На практиці ми часто стикаємося 3 проблемою економічного, організаційного, соціологічного забезпечення нововведень, тобто проблема в існуванні ініціатора змін та сприйняття його користувачами. Деякі дії незавжди $є$ передбачуваними, іноді вони можуть навіть створювати серйозні проблеми для подальшого розвитку педагогічної системи, тобто 
необхідно враховувати соціальну плату за нововведення. Реалізація нововведення завжди вимагає спеціальну підготовку персоналу, аби максимально запобігти або попередити будьякі бар'єри взаємодії в системі всіх суб'єктів освітнього процесу. Поняття «людського фактору». Його розуміння є одним з визначальних у самоорганізації педагогічної системи. Існують суб'єктивні та об'єктивні чинники, що впливають на сприйняття й реалізацію інновацій педагогами.

Так, у літературі знаходимо, що об'єктивними чинниками визначають: стать; вік; місце роботи; освіту або педагогічну підготовку; поінформованість; задоволення та престижність професії; розвинутість та специфіка регіону; місце (місто, село); тип школи; матеріальнотехнічне забезпечення закладу освіти, автономність, співпраця та підтримка громади тощо. Суб'єктивними чинниками $\epsilon$ саме сприйняття, упровадження й розповсюдження нововведень, отже, це є: наявність новаторів в колективах; добре налагоджена система мотивації, сприятливі умови впровадження та розвитку; ініціатор нововведення, об'єктивне бачення перешкод й труднощів в запровадженні та розробка плану і способів реалізації в освітньо-виховному процесі, підготовка здобувачів освіти до правильного сприйняття інноваційних дій педагогів, професійна підготовленість педагогів до інноваційної практики, способи та критерії вибору нововведень та оцінка результатів застосування нововведень у освітньому процесі [1].

Важливе місце в розвитку педагогічної системи посідає правильно організоване управлінське консультування, адже така комплексна робота дозволяє правильно інформувати учасників про нововведення, аналізувати діяльність кожного та створювати резерви ефективності управлінської системи.

3 аналізу інноваційних процесів педагогічних систем, що розвиваються, було визначено ряд рушійних чинників, які можуть створювати додаткові бар'єри, а саме: між досягнутим рівнем педагогічної науки, передової практики, професійної педагогічної культури загалом та станом професійної педагогічної діяльності в інноваційному закладі; потребами освітньої установи та їі можливостями; інноваційними ідеями, що затверджуються в регіоні та станом справ у закладі освіти; прагненням педколективу визнання, здобуття нових позицій та реальними досягненнями освітньої установи; досягненнями в окремих компонентах системи, наприклад, у технологіях навчання або напрямках діяльності та загальним рівнем розвитку інноваційного закладу освіти; досягненнями окремих педагогів та типовим станом діяльності більшості педагогів; інноваційною практикою, що склалася, та освітнім стандартом [1].

Стратегія переходу закладу освіти як педагогічної системи зі стану функціонування в стан розвитку й саморозвитку залежить від чинного законодавства. Сучасна освіта $\epsilon$ продуктивним чинником й умовою розвитку суспільства, вона набула статусу загальнонаціональної стратегії. Як засвідчує «Національна доповідь про стан і перспективи розвитку освіти в Україні» суверенітет України започаткував формування власної державної політики в освіті, зокрема розпочався період національної самоідентифікації, було схвалено ряд Законів «Про освіту», «Про наукову та науково-технічну діяльність», Державну національну програму «Освіта» («Україна XXI століття»). Створено мережу наукових установ, які розробляють методологію, теорію і методику освіти для всіх освітніх рівнів, здійснюють науково-методичне забезпечення модернізації національної системи освіти. Розгорнуто діяльність щодо розширення мережі шкіл, зокрема закладів нового типу i приватної освіти [7].

Однак, слід зауважити що тривалий час хаотично виникали приватні вищі навчальні заклади, що негативно вплинуло на якість надання послуг та рентабельність випускників. Відбувся ще один стрибок у реформі освіти України.

Так, до 2002 років через стійку економічну кризу, слабку правову освітянську базу дещо занепадає дошкільна освіта. Виникає кадровий дефіцит науковців та освітян-реформаторів, підвищується соціальна напруга в освітніх закладах тощо. Упродовж 1998-2002 pp. на державному рівні було прийнято ряд законів, в основу яких було покладено нагальні 
орієнтири всіх рівнів освіти. Так, окрім вище зазначених нормативних документів, були закони України «Про професійно-технічну освіту» (1998р.), «Про загальну середню освіту» (1999 р.), «Про позашкільну освіту» (2000р.), «Про дошкільну освіту» (2001 р.), «Про вищу освіту» (2002 р.), «Про охорону дитинства» (2001р.), «Про соціальну роботу з дітьми та молоддю» (2001 р.), затверджено Національну доктрину розвитку освіти (2002р.). Зокрема, у Національній доктрині розвитку освіти покладено засади стратегій державної освітньої політики в системі вимог нового часу, забезпечення доступності громадян до якісної освіти, реалізації принципів гуманізації, демократизації освіти, можливості створення особистісного освітнього виміру, переорієнтація системи освіти в проблемно-діяльнісний, інноваційний тип освіти та перехід до 12-річної шкільної освіти. Початок 2000-х ознаменувався також впровадженням системи контролю якості освітніх послуг, впровадженням інноватики в освіту та підтримкою обдарованої молоді. Однак, дієвість механізмів упровадження законодавчо-нормативної бази не відбулася на належному рівні. А тому до 2013 року настає період європейської інтеграції та світової глобалізації. Саме в цей період відбуваються процеси формування державної політики в новому методологічному й соціальноекономічному контекстах, оскільки Україна почала суттєво відставати в освітянській та науковій сферах на міжнародному рівні.

Так, 2005 рік у реформі педагогічних систем відзначився роком приєднання України до Болонського процесу, що дозволило б українській освіті створити привабливу й конкурентоспроможну систему вищої освіти з виходом на Європейський освітній простір. Однак, імплементація Болонського процесу в систему освіти України не відбулася на належному рівні, оскільки була невідповідність стандартів і рекомендацій щодо забезпечення якості освіти в Європейському просторі, національної рамки кваліфікацій тощо. Так, система освітнього й наукового законодавства України дещо не відповідала міжнародним документам. Відповідно на законодавчому рівнях було затверджено Національну рамку кваліфікацій (2011р.) та Національні стандарти класифікації освіти (2013 р.). Відповідно розпочався новий етап розвитку педагогічних систем в Україні.

Так, починаючи з 2014 року і до сьогодні відбувається модернізація освітньо-наукової сфери України. Були внесені зміни та затверджені нові закони України «Про вищу освіту» (2014 р.), «Про наукову і науково-технічну діяльність» (2015р.). «Про освіту» (2017 р.). Особливого значення для розвитку системи освіти набула концепція Нової української школи. Так, Нова українська школа - це інноваційний процес та інноваційна педагогічна система, в комплексі вони вирізняють сучасний освітній простір. Варто відзначити, що П. Блонський ще в 1918 р. сформулював провідні риси нової школи, яка, на його думку, повинна стати місцем життя дитини. Отже, нова школа, має формувати творця нового життя у спосіб самовиховання й самоосвіти; нова школа $є$ системою виховання активної думки дитини; також вона є школою життя й творчості самого вихователя. Головне їі достоїнство мало полягати в тому, що в новій школі буде виховуватися людина, здатна до створення свого власного життя, до самовизначення [1; 7]. Можна стверджувати, що майже сто років тому положення П. Блонського «...є пророчими, соціально значущими для організаторів освіти, які визначають пріоритети нової школи XXI століття. Вони важливі для подолання спрощеного, прагматичного розуміння окремими керівниками мети школи, яка озброює виховання лише знаннями, уміннями й навиками» [1;8].

Тривалий час проблема мети й завдань виховання посідає одне 3 центральних місць у творчості видатних українських просвітників. Зокрема, ще у творчості I. Франка, П. Грабовського, М. Драгоманова ми знаходимо ідеї про необхідність всебічного задоволення потреб людини, формування у кожного загальнолюдської культури й збереження нації в цілому [2; 7]. Такої ж концепції дотримуються й сучасні дослідники, мету й завдання виховання вони визначають саме через людину з іiі конкретними життєвими потребами та прагненнями [1]. Наскрізним має стати принцип залучення до самоосвіти всіх суб'єктів освітнього процесу: і споживачів, і надавачів освітніх послуг, і органів громади. 
Набуває інноваційного змісту принцип уміння навчитися вчитися самому та 3 іншими, навчатися впродовж життя. Сьогодні Радою Європи й Свропейського Союзу визначено ключові компетентності для фахівців різних галузей, у такому випадку першочерговим $є$ не процес, а результат навчання, який можна оцінювати за концепцією вимірюваної якості, цей процес повинен бути неперервним, системним і цілісним. Відповідно змінено ключові принципи освітньої політик. Відтак, орієнтація відбувається на формуванні нових базових знань для всіх, збільшення інвестицій для збереження й розвитку людського потенціалу, відповідних ресурсів, впровадження інноваційних технологій в освіті, модернізація системи оцінювання якості здобутої освіти та запровадження постійного моніторингу послуг, впровадження педагогіки співробітництва, розвиток наставництва й консультування, упровадження концепції регіональної, дуальної освіти тощо $[1 ; 3 ; 4 ; 5 ; 8 ; 10]$.

Проте без цілеспрямованої державної політики практично неможливо створювати та розвивати систему нової україно-європейської системи безперервної освіти, існує нагальна потреба в залученні усіх сторін освітнього процесу - від здобувача до працедавця, громади, суспільства загалом; узгодженні стандартів вимог до якості освіти, умов іiі отримання, налагодження якісної управлінської системи прийняття щодо вдосконалення освіти та забезпечення академічної мобільності учасникам освітнього процесу; розвитку державногромадського управління й соціального партнерства в освіті тощо.

Висновки та перспективи подальшого дослідження проблеми. Отже, державна політика в системі освіти визначили пріоритетним розроблення та впровадження комплексної державної програми «Освіта впродовж життя». Створення інноваційної педагогічної системи є колективним творчим процесом, який передбачає диференціювання ролей за різними видами діяльності відповідно до функціональних компонентів педагогічної системи, зокрема гностичного, конструктивного, проектувального, організаторського, комунікативного, та виконання аналітичної, діагностичної, прогнозуючої, програмуючої, оцінної, коригуючої функцій управління тощо.

3 огляду на сказане вище, можемо зробити висновок, що аналіз напрямів модернізації сучасних педагогічних систем в умовах глобалізаційних змін вимагає використання творчого підходу, який дозволить на практиці оптимально правильно орієнтуватися та здійснювати проектування інноваційних педагогічних систем, синтезувати певні види та рівні діяльності, зберігати та створювати умови для самовдосконалення людського ресурсу педагогічної системи. Пріоритетом освітньої політики визначено процес формування такої нації, котра постійно навчається, є носієм розвитку громадянського суспільства, збереження демократичних цінностей, утвердження людиноцентризму в освіті. Це і є та глобальна стратегія, яка повинна докорінно змінити ціннісний i мотиваційний потенціал освіти, зробити іiі особистісно значущою для кожної людини, полікультурною, безперервною, доступною, адаптивною під кожного члена суспільства, якісною для формування майбутнього Свропи.

\section{Список використаних джерел та літератури}

1. Докучаєва В. В. Проектування інноваційних педагогічних систем у сучасному освітньому просторі: Монографія. Луганськ, 2005. 304 с.

2. Кремень В. Г. Філософія освіти ХХІ століття. Педагогіка і психологія. Київ, 2003. № 1. С. 6-16.

3. Лігоцький А.О. Теоретичні основи проектування сучасних освітніх систем: Монографія. Київ: Техніка, $1997.210 \mathrm{c.}$

4. Локшина О. І. Моніторинг якості освіти: світовий досвід. Педагогіка і психологія. Київ, 2003. № 1. C. $108-116$.

5. Масюкова Н. А. Теория и практика проектной деятельности в системе повышения квалификации работников образования: Дис. ... Д-ра пед. наук: 13.00.01. Минск., 2001.

6. Матвієнко О. В. Створення моделі спеціаліста на засадах теорії освітньої інноватики. Педагогіка $i$ психологія. Київ, 2004. № 3. С. 44-52. 
7. Національна доповідь про стан і перспективи розвитку освіти в Україні / Нац. акад. пед. наук України; за заг. ред. В.Г.Кременя. Київ: Педагогічна думка, 2016. 448 с.

8. Психологія і педагогіка життєтворчості: Навч.-метод. посібник / Ред. рада: В. М. Доній та ін. Київ, $1996.792 \mathrm{c}$.

9. Пуховська Л. П. Професійна підготовка вчителів у Західній Європі: спільність і розбіжності: Монографія. Київ: Вища шк., 1997. 180 с.

10. Сорока Г. І. Сучасні виховні системи та технології: Навч.-метод. посібник для керівників шкіл, вчителів, класних керівників, вихователів, слухачів ІПО. Харків. 2002. 28 с.

\section{References (translated \& transliterated)}

1. Dokuchaieva, V. V. (2005). Proektuvannia innovatsiinykh pedahohichnykh system u suchasnomu osvitnomu prostori [Design of innovative pedagogical systems in the modern educational space]: Monohrafiia. Luhansk. 304 p. [in Ukrainian].

2. Kremen, V. H. (2003). Filosofiia osvity KhKhI stolittia [Philosophy of education of the XXI century]. Pedahohika i psykholohiia. Kyiv. № 1. Pp.6-16. [in Ukrainian].

3. Lihotskyi, A. O. Teoretychni osnovy proektuvannia suchasnykh osvitnikh system [Theoretical foundations of modern educational systems design]: Monohrafiia. Kyiv, 1997. 210 p. [in Ukrainian].

4. Lokshyna, O. I. (2003). Monitorynh yakosti osvity: svitovyi dosvid [Monitoring the quality of education: world experience]. Pedahohika i psykholohiia. Kyiv. №1. Pp.108-116. [in Ukrainian].

5. Masiukova, N. A. (2001). Teoryia y praktyka proektnoi deiatelnosty v systeme povyshenyia kvalyfykatsyy rabotnykov obrazovanyia [Theory and practice of project activity in the system of advanced training of educators]: Dys. ... d-ra ped. nauk: 13.00.01. Minsk., 2001. [in Russian].

6. Matviienko, O. V. (2004). Stvorennia modeli spetsialista na zasadakh teorii osvitnoi innovatyky [Creating a specialist model based on the theory of educational innovation]. Pedahohika i psykholohiia. Kyiv. №3. Pp. 44-52. [in Ukrainian].

7. Natsionalna dopovid pro stan i perspektyvy rozvytku osvity v Ukraini [National report on the state and prospects of education in Ukraine] (2016). Nats. akad. ped. nauk Ukrainy. Kyiv, 2016. 448 p. [in Ukrainian].

8. Psykholohiia i pedahohika zhyttietvorchosti [Psychology and pedagogy of life creation ] (1996). Navch.metod. posibnyk. Ed. council: V.Doniy and others. Kyiv. 792 p. [in Ukrainian].

9. Pukhovska, L. P. (1997). Profesiina pidhotovka vchyteliv u Zakhidnii Yevropi: spilnist i rozbizhnosti [Teacher training in Western Europe: commonalities and differences]: Monohrafiia. Kyiv. 180 p. [in Ukrainian].

10. Soroka, H.I. (2002). Suchasni vykhovni systemy ta tekhnolohii: Navch. -metod. posibnyk dlia kerivnykiv shkil, vchyteliv, klasnykh kerivnykiv, vykhovateliv, slukhachiv IPO [Modern educational systems and technologies: Teaching method. manual for school principals, teachers, class teachers, educators, IPO students]. Kharkiv. 28 p. [in Ukrainian].

Статтю отримано 08.10.2020 p.

Прийнято до друку 10.11.2020 p. 